\title{
EFEK PENEMBAKAN LASERPUNKTUR PADA TITIK OVA BEBEK MOJOSARI JANTAN TERHADAP JUMLAH SEL SERTOLI DAN LEYDIG
}

\section{EFFECT OF LASER ACUPUNCTURE SHOOT ON OVA POINT OF MALE MOJOSARI DUCK (Anas Plathyrhynchos) ON THE NUMBER OF SERTOLI AND LEYDIG CELLS}

\author{
Yuanara Augusta Rahmat Adikara ${ }^{1)}$, Suzanita Utama ${ }^{2)}$, Ira Sari Yudaniayanti ${ }^{3)}$, \\ R.T.S Adikara ${ }^{4}$, Abdul Samik ${ }^{5)}$, Eka Pramyrtha Hestianah ${ }^{6}$ ) \\ ${ }^{1)}$ Student,${ }^{2)}$ Veterinary Reproduction Department, ${ }^{3)}$ Clinic Department \\ Faculty of Veterinary Medicine, Universitas Airlangga \\ yuanaraaugusta@gmail.com
}

\begin{abstract}
Demand for eggs and duck meat lately increased along with the increasing interest of the community to consume eggs and duck meat. Due to that reason researcher try to find the best way to enhance the reproductive ability of livestock., which is in this research by laserpuncture shot. This research used 3 treatments: the control group, first treatment with laserpuncture shot dose of $0.2 \mathrm{~J}$, second treatment with laserpuncture shot dose of $0.4 \mathrm{~J}$. Data was analyzed with ANOVA and further test by Duncan Multiple Range Test. Research result proved that Laserpuncture shot with dose of $0.2 \mathrm{~J}$ and $0.4 \mathrm{~J}$ decrease the number of sertoli and leydig cells.

Keywords : Mojosari duck, laser acupuncture, sertoli cells, leydig cells
\end{abstract}

\section{Introduction}

Food is a critical issue currently faced by all countries in the world. In 2013 commotion occurred in the Indonesian market regarding the price of meat, especially beef. The issue arises because the demand for beef continued increasing (Atmakusuma et al., 2014). Besides focusing on the procurement of beef, poultry meat turned out to give a significant role in the availability of national meat. Development of poultry farm is also a priority, because the public demand of poultry increase considering the growth and production of poultry is faster than ruminants or non poultry (Nugroho, 2004).

Demand for eggs and duck meat lately increased along with the increasing interest of the community to consume eggs and duck meat. Public interest in the duck meat is almost equivalent to the public interest in chicken meat. This increasing demand needs to be balanced with the provision of the quality of seedlings duck in quantity and sustainability. The seedling supply will indirectly support the development of duck farms and encourage the creation of technology that affect ducks growth.
The use of alternative technologies as the intensification duck breeding in order to obtain the expected results have been necessary (Hardjosworo and Rukmiasih, 2000). Laser acupuncture shoot on GV-4 point, in both male and female garut sheep gave positive effect that was improvement of reproductive organ function (reproductive acupuncture point in both male and female sheep were in the same place) (Herdis, 2010). In the poultry, acupuncture point that stimulate female reproductive organ was found in the dorsal region joint between last thoracic and first lumbar (Adikara, 2001). Therefore, writer interested in ova point, is this point give same effect if the shooting was done in the male poultry. Because if the laser acupuncture technology as an alternative technology can overcome these problems, it will solve the needs of seedlings. Laser utilization in livestock aimed at improving the biological balance and health of livestock, besides the important thing is to improve the productivity of livestock and can also enhance the reproductive ability of livestock. To achieve the above objectives, the laser is fired at the points associated with the organ that serves to health, balance, production, 
and reproduction in livestock (Adikara, 2001).

\section{Method and Materials Research Location and Time}

The study was conducted from May until June 2016 in the experimental animals cage of the Faculty of Veterinary Medicine, Universitas Airlangga, Surabaya, East Java.

\section{Research Materials}

The materials used in this study were 18 , five month old male mojosari ducks. Ducks were in healthy condition and had entered the age of sexual maturity that ranged in age from 5 month. $20 \mathrm{~mW}$ semiconductor equipment for Laser acupuncture that can be adjusted the power and dosage to use automatically. Eighteen pieces of battery cages for the ducks (one cage for one duck), feed and drink containers, ducks feed for the finisher phase and vitamins to keep the duck immune system.

\section{Research Method}

Prepare the battery cages for adult ducks, equipped with places to eat and drink, for the placement of experimental animals. Ducks were randomly divided into three groups, which are $\mathrm{P}_{0}$ (control), $\mathrm{P}_{1}$ which treated with laser acupuncture shoot dose of 0.2 Joule and $\mathrm{P}_{2}$ with dose of 0.4 Joule. Laser acupuncture shot at the point of reproduction carried out for one month with an interval of three days.

\section{Treatments}

There were 3 treatments in this research with 6 replicates each treatment :

1. Control (P0) : Mojosari duck without any laser acupuncture shoot

2. Treatment $1(\mathrm{P} 1)$ : Mojosari duck shot with laser acupuncture dose of $0.2 \mathrm{~J}$

3. Treatment $2(\mathrm{P} 2)$ : Mojosari duck shot with laser acupuncture dose of $0.4 \mathrm{~J}$

\section{Sertoli and Leydig Cells Calculation}

After going through the treatment in three groups of experimental animals for 30 days, all the ducks were slaughtered and dissected to collect the testes. After slaughtering, surgery were performed on ducks by opening the abdominal cavity and removed a pair of testes, then the testes that have been taken were stored in pastic pot con- taining $10 \%$ formalin at least for 3 month. After that, make the histological slide.

Under microscope with 400x magnifycation, the number of Sertoli and Leydig cells in the groups $\mathrm{P}_{0}, \mathrm{P}_{1}$ and $\mathrm{P}_{2}$ were counted. On histological slide visual field, counting was performed on two different pieces of testicular from each treatment. Each pieces is done in the field of view of five different seminiferous tubules starting from the corner of the left, right, top, bottom and middle part of the histological slide (Legowo, et al. in Khanif, 2012). After the completion of the counting, averaged the amount of sertoli and leydig cells in order to get the results of the calculation.

\section{Data Analysis}

The design of the research conducted in this study is completely randomized design (CRD). The data is processed and analyzed by ANOVA followed with advanced Duncan showed significant differences $(\mathrm{p} \leq$ 0.05 ) between groups using SPSS statistical calculations.

\section{Results and Discussion Sertoli and Leydig Cells Counting Re- sults}

Histological slide examination on Leydig and Sertoli cells were carried out to observe the effect of laser acupuncture shoot on reproductive point of mojosari male duck. The amount of Leydig and Sertoli cells of each group were analyzed using ANOVA followed with Multiple Range Test (Duncan) (Table 1).

Duncan's multiple range test analysis showed that ducks received $0.4 \mathrm{~J}$ shot $\left(\mathrm{P}_{2}\right)$ reduced the number of Leydig and Sertoli cells more than duck received $0.2 \mathrm{~J}$ shot $\left(\mathrm{P}_{1}\right)$ and the control group $\left(\mathrm{P}_{0}\right)$. There are differences in the leydig and sertoli cells number. The fewest number of both cells is on $\mathrm{P}_{2}$ and the largest number of both cells is on $\mathrm{P}_{0}$.

Leydig and Sertoli cells analysis showed the significant difference which mean that the laser acupuncture shoot gives significant result $(\mathrm{p}<0.05)$. It showed that laser acupuncture shoot on ova point decrease the number of leydig and sertoli cells. The result then analyzed by ANOVA with Duncan's multiple range test. After Duncan's multiple range test, it is known 
that the $0.2 \mathrm{~J}$ and $0.4 \mathrm{~J}$ dose can not increase the number of leydig cells because the result of $0.2 \mathrm{~J}$ and $0.4 \mathrm{~J}$ dose to control are significantly different. From that result can be seen that the $0.4 \mathrm{~J}$ decrease the number of leydig and sertoli cells more than $0.2 \mathrm{~J}$ dose and control.

Mechanism of acupuncture stimulation began with the start of initial stimulation, that is laser acupuncture shooting at acupuncture point as a group of active electricity cell, will lead to a special activity for the cells group in the form of rRNA stimulation, mRNA activation, and protein synthesis. Specific pathway connecting one point to another point toward the final terminal which is organ (Herdis, 2010).

Table 1. Number of Leydig and Sertoli Cells (Mean \pm SD) of male Mojosari ducks shot with laser acupuncture on reproduction point

\begin{tabular}{lll}
\hline & Leydig Cells & Sertoli Cells \\
\hline $\mathrm{P}_{0}$ & $62.51 \pm 2.32^{\mathrm{a}}$ & $31.48 \pm 0.40^{\mathrm{a}}$ \\
$\mathrm{P}_{1}$ & $47.95 \pm 1.90^{\mathrm{b}}$ & $23.06 \pm 0.69^{\mathrm{b}}$ \\
$\mathrm{P}_{2}$ & $35.56 \pm 1.85^{\mathrm{c}}$ & $12.93 \pm 0.57^{\mathrm{c}}$
\end{tabular}

a,b,and $\mathrm{c}$ different superscript in the same column indicates a significant difference $(\mathrm{p}<0.05) ; \mathrm{P}_{0}$ : Control Group, without laser acupuncture shot; $\mathrm{P}_{1}$ : ducks received $0.2 \mathrm{~J}$ laser acupuncture shot; $\mathrm{P}_{2}$ : ducks received $0.4 \mathrm{~J}$ laser acupuncture shot; Replicates $=6$; Shots were repeated $10 \mathrm{x}$ with 3 days interval.
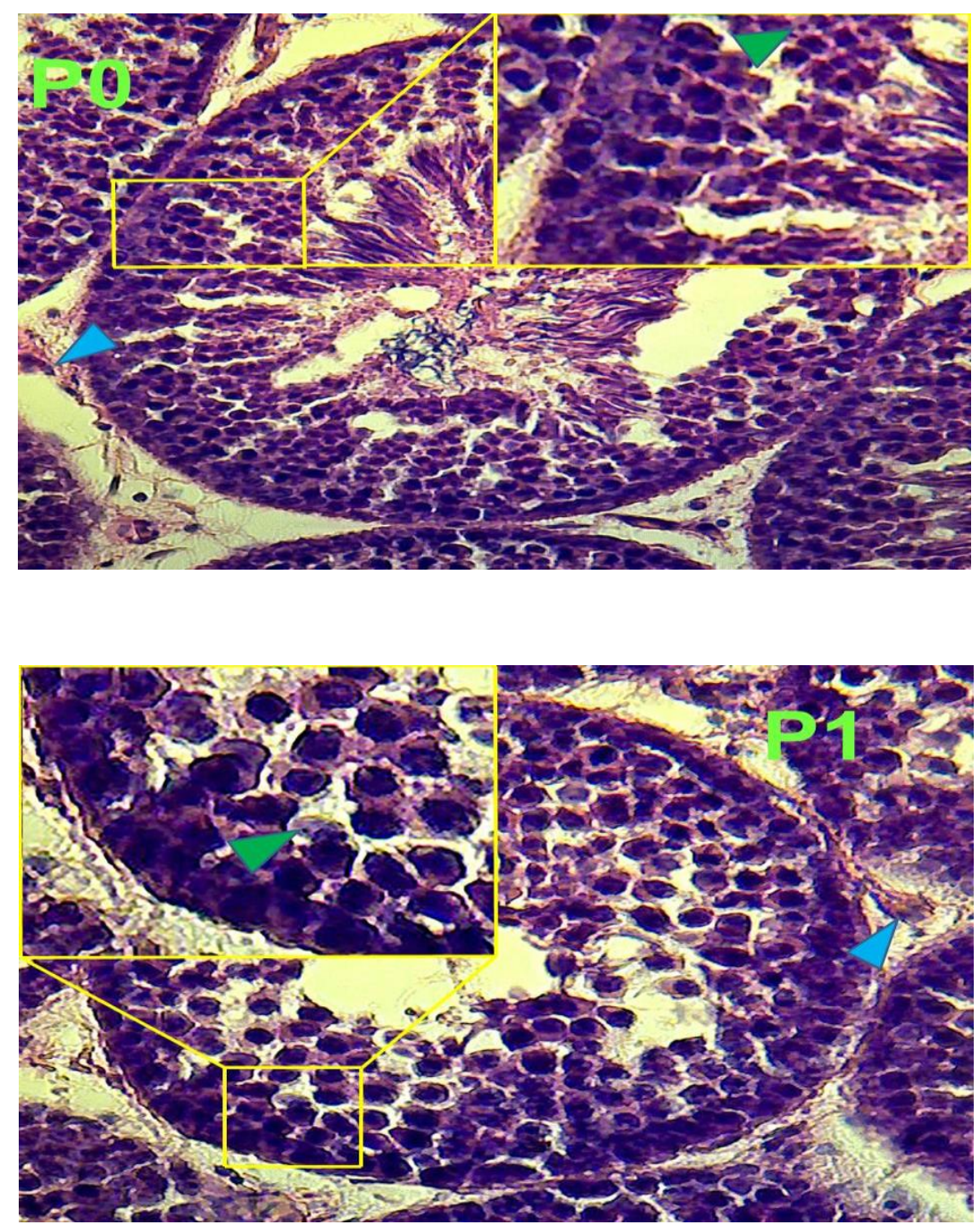


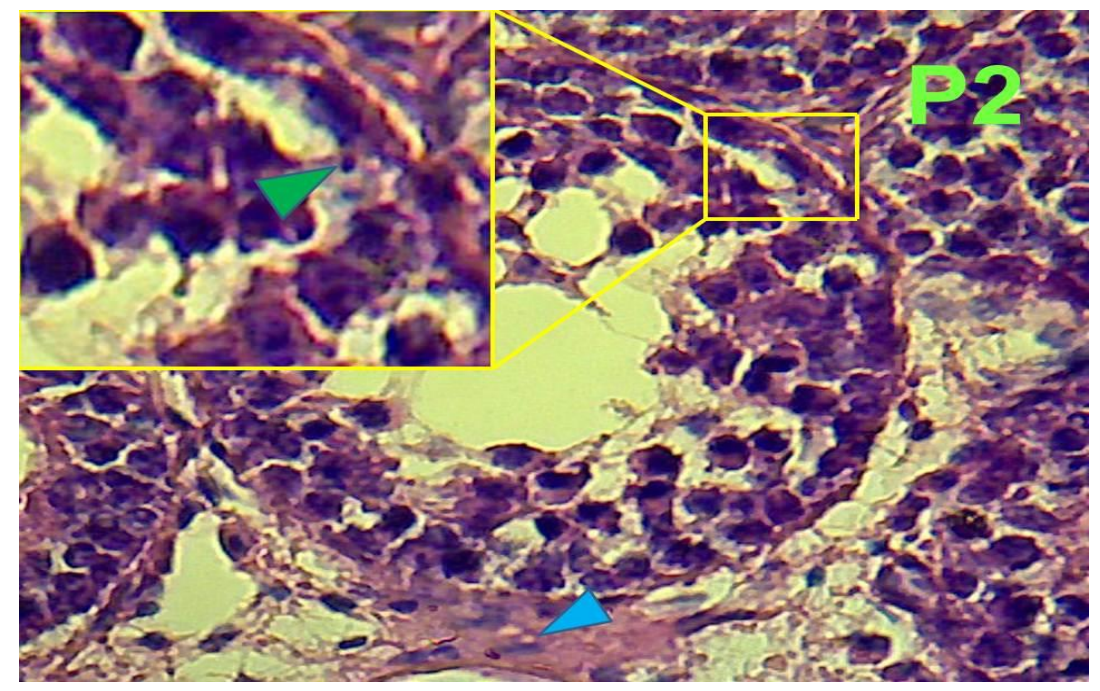

Figure 1. Seminiferous tubule of mojosari duck of each treatment (HE stain; 400x Magnification). Green arrowheads shows Sertoli cell. Light blue arrowheads shows Leydig cell.

Acupuncture stimulation travel path in the female poultry reproduction which is ova point travel from nerves stimulation to the bone marrow that continues the stimulation into brain. Brain stimulates hypothalamus to secrete $\mathrm{GnRH}$ that continue the stimulus into ovarium. In the male poultry, it is expected that the stimulation travel to testes with hope to stimulates the growth of sertoli and leydig cells. Hypothalamus secrete Gonadotropin Releasing Hormone (GnRH) to stimulate the pituitary gland to secrete Follicle Stimulating Hormone (FSH) and Luteinizing Hormone (LH). FSH role is to stimulate sertoli cells to produce estrogen or estradiol, while LH role is to stimulate leydig cells to produce testosterone in male. Interference with the secretion of FSH and LH can disrupt the process of spermatogenesis (Prajogo, 2007).

Laser acupuncture shoot on GV-4 point, in both male and female garut sheep improve reproductive function (male and female sheep reproductive acupuncture point in the same point) (Herdis, 2010).

Meanwhile, in the poultry known that ova point which analogous to GV-4 point in mammals improve female reproductive function in poultry (Binawati, 2003). This led to speculation that ova point improve male reproduction function in male poultry because specific acupuncture point for reproduction for male poultry is still undiscovered, given that the male and females sheep reproductive point are in the same point. After laser acupuncture shoot with $0.2 \mathrm{~J}$ and $0.4 \mathrm{~J}$ dose was done, the results turns out that the number of sertoli and leydig cells were decreased significantly. From this point can be seen that ova point which improve reproductive function in female poultry did not give same effect in male poultry. So, it is suspected that ova point is a point specifically for female poultry not for male poultry.

Sertoli plays an important role in the differentiation and development of testicular function. The number of sertoli cells in the testes definitely determine the testicular size and sperm production so any damage or decrease in the number of sertoli cells will automatically reduce the sperm production and increase the number of abnormal sperm, resulting in infertility (Schulz et al; 2005). Decrease in sertoli and leydig cells can not be known with certainty because in the hypothesis the laserpuncture shot was predicted to improve the number of both cells. It can be caused by some kind of substance or compound that inhibit the gonadotropin hormone that have contradictive function from substance or compound that improve the male reproductive system or another hormonal factor. Decrease in sertoli and leydig cells supported by testicular size reduction from control group to each treatment respectively with $0.4 \mathrm{~J}$ dose testes was the treatment with smallest testes size. Testicular size reduction can be caused by hormones imba- 
lance caused from laser acupuncture shooting on ova point or laser stimulation which produce excessive energy. There is a possibility that the stimulation went to leydig cells and the energy received by leydig cells is too much causes leydig cells to ruptured so testosterone levels decreased. Laser acupuncture shooting on ova point improve reproductive function in female poultry so there is a possibility that laser acupuncture on ova point improve the female reproductive hormone leading to excessive increase in one hormone that cause other reproductive hormone to decrease. There is possibility that testes size have correlation with GnRH secretion and testosterone levels, as the increase in both testes size and testosterone production is ultimately under control of GnRH secretion, any association between testes size and testosterone production may instead be due to differences in the production of GnRH by hypothalamus (Thibault, et al; 1993 in Preston, et al; 2011). Testes with greater amounts of spermatogenic tissue require, and are supplied with, higher levels of testosterone (Preston et al; 2011)

\section{Conclusion and Suggestion Conclusion}

Laser acupuncture shoot on ova point of male mojosari duck decrease the number of sertoli and leydig cells.

\section{Suggestion}

Need to find the cause of sertoli and leydig cells number decline and then do the RIA blood test to determine the hormones level. Then use different point than ova point like Ming Men/GV-4 based on mammals anatomy analog. Last is do the observation of sperm quality, and hatchability of mojosari duck to strengthen the result of the effect of laser acupuncture shoot on ova point of mojosari male duck.

\section{References}

Adikara, R.T.S. 2001. Teknologi Laserpunktur Pada Ternak. Pusat Penelitian Bioenergi. LKPM Universitas Airlangga. 64-67.
Atmakusuma, J., Harmini dan R. Winandi. 2014. Mungkinkah Swasembada Daging Terwujud ?. Risalah Kebijakan Pertanian dan Lingkungan. 1(2): 105 -109 .

Binawati, D.A. 2004. Pengaruh Laserpunktur Terhadap Dewasa Kelamin, Produktivitas Telur dan Kualitas Telur Ayam Arab [Thesis]. Fakultas Kedokteran Hewan. Universitas Airlangga.

Hardjosworo, P.S dan Rukmiasih. 2000. Meningkatkan Produksi Daging Unggas. Penebar Swadaya, Anggota IKAPI. Jakarta.

Herdis. 2010. Aplikasi Teknologi Laserpunktur dalam Meningkatkan Libido Pejantan Domba Garut (Ovis Aries). Jurnal Sains dan Teknologi Indonesia. 12: 25-30

Khanif. 2012. Gambaran Histopatologi Testis Mencit (Mus Musculus) yang Diinfeksi dengan Toxoplasma Gondii [Skripsi]. Fakultas Kedokteran Hewan. Universitas Airlangga.

Nugroho, S. 2004. Subtitusi Ampas Kecap Dalam Pakan Komersial Terhadap Presentase Karkas dan Presentase Lemak Abdominal Itik Mojosari Jantan [Skripsi]. Fakultas Kedokteran Hewan. Universitas Airlangga.

Prajogo, E.W.-B. 2007. Pengaruh Daun Justicia Gandarussa Burm f. Terhadap Spermatogenesis Mencit. Jurnal Ilmiah Keluarga Berencana dan Kesehatan Reproduksi. 1-8

Preston, B.T, I.R. Stevenson, G.A. Lincoln, S.L. Monfort, J.G. Pilkington and K. Wilson. 2011. Testes Size, Testosterone Production and Reproductive Behaviour in a Natural Mammalian Mating System. Journal of Animal Ecology. 81: 296-305.

Schulz, R.W., S. Menting, J. Bogerd, L.R. Franca, D.A. Vilela and H.P. Godinho. 2005. Sertoli Cell Proliferation in the Adult Testis--Evidence from Two Fish Species Belonging to Different Orders. Biology Reproduction. 73: 891-898. 